\title{
Index
}

acculturation $6,24,44-5,50,500$

health 423

health behaviour and 66-70

young people, of 434

stress 25

Amsterdam Declaration 'Towards

Migrant Friendly Hospitals in an

Ethno-Culturally

Diverse Europe' 459

anti-immigration rhetoric $4,341,352$, 470

asylum seekers $175,177-8,515-16$

see also human trafficking; irregular migrants

access to healthcare 309

children see children; child welfare

chronic illness, and 306-8

UK, in $308-12$

denying claims of 103,135

deportation of 174

disability, and $306-8$

$\mathrm{UK}$, in $308-12$

entitlements 308

France, in 162-3

Israel, in 110-13

legal status 104, 300, 308

mental health of see mental health

reception/detention centres 174 , 181-3

securitisation 188

structural barriers 308

support policies in receiving countries 109, 148, 300, 309, 420

trafficked people $217-18$

unaccompanied minors see unaccompanied minors

young people see young people

work status 103-4

Australia

detention centres $174,181,182-3$

determining immigration status

181-2 migrant healthcare in 444-5, 447-9

accessing 445-6

policy $447-8$

practice $448-9$

multiculturalism in 442-4

occupational health and safety 259 , $261,262-4,268$

undocumented workers, of 257

racism in $264-5$

refugee healthcare in 444-5

resettlement country, as 380

skilled workers, wanting 254

temporary protection visas 186

women 'at risk' 184

Youth Health Policy 447

barriers

accessing healthcare, to 222,223 , $241,246,309,368,519$

young migrants $429-33,445,446$

cultural 410-11, 431-2

disabled persons, to see disabled persons

educational 311-12

health, to 429

lack of information 429-31

language 240, 411, 432-3

legal 39

social $25,30,197$

structural 30, 161, 308, 352, 459-60

biological sex

see also gendered discourse

migrant health, of 54

birth outcomes $64-5$

see also pregnancy

health behaviour and 67

border control 5, 137, 150-52, 181, 350

Europe, in 134

unauthorised border crossing 104 , 108

borders 137

sovereignty 138 


\section{Handbook of migration and health}

Charter of Fundamental Rights of the European Union (2000) 224 children

see also deservingness; young people

adaptation 423-4

age assessment 201, 202, 203

child obesity $50-52$

conducting research with 425-6

deportation see deportation

deservingness 112

inalienable rights of 137

irregular migrants, as 135

legal competence of 421

mediators, as 50

migration control and 134-5

post-migration health $36-7$

protecting see child welfare

violence against 390

child welfare

access to healthcare 134-7

case studies 139-42, 152

discretionary judgements and 138-9, 143, 145-50

irregular migrant children, of 139-42, 144-5, 148, 153

Norway, in 135, 143-4

'best interest' of the child 149

'pirate daycare' (Israel) 110-13

refugee camps, in 385-6

chronic illness 305

see also disability; noncommunicable diseases

asylum seekers with 306-7

case study $308-12$

disability, as 301-2

HIV as 344,351

climate change 10, 277

amplifying migration 290

case studies

flooding 285

Hurricane Katrina 289

Morocco 283-4

Northwest Alaska 282

Pacific Islands 287

Sri Lanka 286

health risks of $287-8$

Intergovernmental Panel on Climate Change 278

left-behind populations, and 289 -related migration $277-80$

adaptive response, as 286, 290

complexity of 277-8

displacement 284-5, 291

health outcomes $279,280-81$, 291

policy responses to $290-91$

resettlement 286-7

return 288-9

risk management, as 286

transit migration 283-4

communicable diseases 13,49 , 357

see also chronic illness; epidemiology; noncommunicable diseases

Chagas disease 369-70

epidemiology see epidemiology

hepatitis B

EU/EAA, in 364-6, 370

global scale 364

testing 366

HIV see HIV

measles

EU/EAA, in 366, 367-8

vaccination 366,367

migrant population in EU/EEA, in $357-8$

migrants disproportionately affected by 305

morbidity and see morbidity

mortality and see mortality

refugee camps, in 383-4

risk factors for 383

rubella

EU/EAA, in 366-7

vaccination $366,367-8$

sexually-transmitted diseases 222

socioeconomic factors, and 371

TB 59

EU/EAA, in 362-4, 370

global scale 361

-HIV co-infection 363

multi-drug resistant 363

Conference on Sustainable

Development (Rio+20) 232

Council of Europe Convention on

Action against Trafficking in

Human Beings (2005) 223-4

see also human trafficking 
cultural competence 4, 463-5, 470-71

access to healthcare, in 460-63, 464-5

case studies cultural consultation 470 intercultural care training 469 migrant use of HIV services 464 defining 'culture' 464 good practice 465 availability of interpreters 466-7 intercultural mediation 467-8 health worker education 468-70 migrant healthcare, in 459 othering, and 463 stereotyping, and 463 whole organisation approach 459-50 youth sexual health education, in 450-51

cultural humility 451-2

cultural inheritance 44, 50 child obesity, and 50-52 generational issues, and 83 pressures of 81

death see end-of-life-care deportation 185, 307, 460 children, of 142 , 202, 205-6

deportability 142, 144, 152, 202, 203, 247

fear of $185,257,310,311,430$

irregular migrants, of 174,179

pregnancy, on 80

sick people, of 109, 110, 140, 247

vulnerability to 307

deservingness 7-8

assessments 97, 99, 114

children, of 112,152

context of $97,102,110$

debates 95-6, 100, 106-13

family status and 105

health-related 95-7, 98-9, 108, 109-10, 151-2

legal status and 104, 107-8

migration motives and 103

moral valuation of $104-5,108$, 113-14

vulnerability and 105-6, 109, 110-13

welfare, and 98

deskilling 81, 86, 128 detention centres $174,182-3$

children in 183-4

diasporic networks see transnational networks

disabled persons

access to healthcare $300,304-5$ structural barriers 304-5, 306, 309-10

barriers facing 299-300, 304-5, 307, 312

case study (UK) 308-12

informal care of 310-12

invisibility of 310

lack of rights 304

migration policies, and 299-300, 304-6

vulnerability of 309

disability

see also chronic illness

asylum seekers with 306-9

case study (UK) 308-12

complexity of needs 312

bio-psychosocial model of 302-3

chronic illness as 301-2

HIV see HIV

human rights issue, as 302

socio-cultural constructions of 302

stigmatisation of 304,306

discrimination $30,187,368$

see also racism

gender-based 519

structural 206, 244, 264, 312, 493

workplace 265

economic benefits 21

maximising 33

socio- 35

economic migrants 175,256

see also labour migration; migrant workers

employment

see also foreign domestic labour; health workers

deskilling 81, 128

domestic labour 79-80, 82

feminisation of 76-7, 128

health/care work 86

informal 81

employment law

Australia, in 257 


\section{Handbook of migration and health}

Canada, in 244

Ireland, in 257

Kuwait, in 255

Qatar, in 255

undocumented workers, and 257

United Arab Emirates, in 255

$\mathrm{UK}$, in 257

USA, in 255

end-of-life care 14-15, 515

burden of $517-18$

culturally sensitive 515

death 15

burial societies $524-5$

foreign country, in 523-5

funeral parlours 525-6

repatriation for burial 525-6

palliative care 515,520

returning 'home' to die 517-18, 522

care at 'home' 518-19

non-state actors and 520-23

South Africa, in 517

epidemiology

cause-specific mortality 61

child health, of 385

climate-change related health risks 282-3, 288

communicable disease, of 363-5

country-of-origin health 63

disease incidence patterns 61

epidemiological paradox 21-2, 64

salmon bias hypothesis 24

HIV see HIV

life-course 46-9

exposures 48

phases 47, 49

mental health, of 391,395

non-communicable diseases 60 , 61-2

ethics

care, of $309-10$

health worker migration, of 7,119 , $120,126-8$

health worker shortage, of 121

medical 8, 141, 146, 148

policy ethics 129

recruitment 125

EU/EAA

border control 134

communicable diseases in see communicable diseases migrant crisis $4,134,239,515-16$

migrant population in $357-8$, 422-4

European Convention on Human

Rights, Article 310

see also human rights

European migrant crisis see EU/EAA

European Social Charter (1961)

224

European Union Framework Directive 2011/36 224

see also human trafficking

exile

see also refugees

Chilean experience in UK 322-4

access to healthcare 326-30

solidarity networks $323,330-31$, 335

resilience 320-22

community and 330-31, 333-4

gender dimensions of 321,331

political activism, and 331, 332-3

solidarity, and 331-2

exiles

activist 322

mental health of see mental health

family

extended 485-6

normative understanding of 486

transnational see transnational families

feminisation

migration, of 76-7, 187, 236

neoliberal globalisation and 76

poverty, of 76

work, of 76-7, 128

flexible citizenship 79

food security 286, 387, 389

forced labour see human trafficking; migrant workers

forced migration 44, 175, 234, 478

see also internal displacement; survival migration

camps $180-81$

healthcare in 187

detention of migrants 181-3

internal displacement 175, 177

media representation of 179

mental health and 30 
forcible removal 109 see also deportation

foreign-born workers see migrant workers

foreign domestic labour 76, 79-80

see also vulnerability

vulnerability of 80

functional ignorance 5

gender

equality $36,334,439-40$

ideologies $83,84-5$

inequality 36,80

power dynamics 35,36

gendered discourse 75, 76

see also intersectionality

migrant health, of 54

norms 318,335

productive labour 79-80

reproduction 80-81

social relationships, of $82-3$

globalisation

intersectionality and 77-8

health worker migration, and 128

neoliberal 75-7

feminisation of work, and see feminisation

hierarchies of 86-7

global migration scale 44, 59, 75, 173 , 235

measuring 345-6

governance

children's voice in 422

labour migration, of 233

health

WHO definition 382

health behaviour

see also health risks

acculturation model 66-70

alcohol consumption $67-8,82$

definition 59

maternal 60

non-communicable diseases and 60 , 61-2

obesogenic environmental factors, and 69

risky $36,60,83$

smoking 67, 68, 69

stressors in 82 healthcare

see also cultural competence; deservingness

access to $70,84,119$

child see child welfare

Chilean exiles in UK 326-30

disabled persons see disabled persons

petty sovereigns and 136, 138-42

attitudes to $434-5$

barriers to 241

cultural differences 431-2

lack of information 429-31

language 432-3

cultural competence in 459

good practice in 465-70

informal carers 310-11

irregular migrants, for 150-51

labour see health workers

medical humanitarianism 151

migrants to Australia, for 444-5

needs $11-12$

policies

Australia, in 447-9

political/humanitarian divide $150-52$

priorities 11-12

privatisation of $76,98,128,129$, 409-10

provision $12-13$

children, for see children

older people, for see retirement migration

refugee camps, in 187, 382, 385

sexual/reproductive see reproductive health; sexual health

racism in $82,99,161$

refugee camps, in see refugee camps refugees in Australia, for 444-5

socio-spatial dimensions of see socio-spatial dimensions of healthcare

state sovereignty and 136-7

trafficked persons, for $222-5$

uptake of 70,84

health effects/outcomes 25-31, 62-3, 65-6, 87, 240

see also child welfare; health risks;

health selection

causal 25-6 
chronic illness 185

climate change-related migration, of $280-81$

detention, of 182

health advantage 25

left-behind households $31-8$ remittances see remittances

long-term 29

mediating factors $21,25,26,28$

mental 29-31, 185-6

gender, and 30, 31

rural-urban migration, and $30-31$

'pirate' daycare, of 111-12

physical 26-9

return migration, of 242

risk behaviours 29,33

risk factors 66

trafficked persons, of see human trafficking

health equity $120,127,129$

health inequity $44,47,81,127$

stress as $84-5$

health risks 45-9

see also communicable diseases; epidemiology; health behaviour, risky

climate change-related $280-81$, 287-8

female 54

migrants as 166

occupational 96, 237, 259

obesity $50-52$

pre-migration 282

reproductive 384

return travel, of 358

second/third generation 49-50

trafficked persons, of 212

in transit 214

living conditions 217

physical violence 214

sexual violence 214-15

work conditions 216-17

transit, in 283-4

health selection $21-5$

see also health effects; migration-

health link

effect 23

epidemiological paradox 21-2, 64

health screening 22 healthy migrant hypothesis $19,22-4$, 26

internal migration and 23

testing 22-4

internal migration in China, and 24-5

labour migrants, of 244-5

pre-migration health 19,23

return migration

'salmon' bias hypothesis $21,24-5$, 516

health status 22 ,

deterioration in 81,461

influences on 60,231

return migration and $349-50$

health tourism see medical tourism

health workers

deskilling of 128

migration

benefits to source countries 126

ethical issues of 120-21, 125, 129-30

gender, and 127-8

globalisation, and 128

human rights issues of 122-4

obligations of receiving countries 123-4

push/pull dichotomy 121

privatisation, and 128, 129-30

push/pull dichotomy 121, 123, 235, 278,515

recruitment 125

source country shortages 120, 126

responsibility for 121

unequal global distribution 119-20

hepatitis B see communicable diseases

HIV 59

see also deservingness

accessing treatment/care 349-50, 351

antiretroviral therapy 342

chronic condition, as 344,351

conflict settings, in 351

deservingness and 105-6

generalised epidemics 341, 343, 344

global scale of 359

local epidemics 347

migrant population in EU/EEA, in 359-61

late diagnosis 360

pandemic 341 
post-conflict situations, in 351

prevalence 341

refugee camps, in 386-7

risks

migrant status and 351

women, of 348-9

services, accessing 464

structural drivers $341-2$

sub-Saharan Africa, in 341-2, 351

-TB co-infection 363

testing 361

transmission

mobility and 340-41, 343, 347, 348-9

human capital

human immunodeficiency virus see HIV

Humanitarian Reform Agenda (2005) 382

human rights

children, of 136-7

health as 3, 123, 439

migration factor, as $122-3$

obligations of receiving countries 123-4

protecting 124

universal 137

human trafficking 9, 211

children 196

definition 211

dynamics of 211-12

forced sex work, for 211, 212, 213, 214-15

health needs of trafficked persons $222-5$

health outcomes

mental 220-21

physical 218-19

sexual/reproductive 221-2

health risks of 212

in transit 214

living conditions 217

physical violence 214

sexual violence $214-15$

work conditions $216-17$

human rights violation, as 211

pre-trafficking health factors 212-14

psychological violence in 213 , 215-16

scale of 211,234
ICESCR see International Covenant on Economic, Social and Cultural Rights

IDPs see refugees, internally displaced persons

illegal immigrants see irregular migrants

infectious diseases see communicable diseases

informal labour 78

precarious, as 81

integration

de facto 379

de jure 379

Inter-Agency Standing Committee 382

Intergovernmental Committee on European Migration 323

internal displacement see also forced migration; survival migration

health burdens of 177

forced migration, as 175, 177

internally displaced persons see refugees

voluntary, as being 287

internal migration 3, 39

see also labour migration

health vulnerabilities 27,34

internal displacement see refugees

rural-urban 19, 30-31, 478

scale of see global migration scale

survival migration see survival migration

International Conference on

Population and Development

(1994) 439

International Covenant on Civil and

Political Rights 122-3

see also human rights

International Covenant on Economic,

Social and Cultural Rights (1966)

$123,124,224$

international migration

definition 44

scale of see global migration scale

intersectionality 75

see also gendered discourse

dynamics of 78-81

globalisation, and 77-8

impacts of $81-5$ 
irregular migrants $134,138-8,176$

see also deportation; deservingness; precariousness; vulnerability children 135, 152

deservingness and 95

definition 135, 233

deportation of 174

detention of 181-3

global numbers of 234

healthcare for $146,150-51,153$

limited access to 308

health risks $369-70$

incarceration of 174

mass deportation of 174

migration status of 136-7,

numbers of 234

precariousness of 257

transit migration and 283

vulnerability of 233-4

Israel

asylum seekers in 110-13

'pirate daycare' in 110-13

Joint Working Group for the

Resettlement of Refugees 323

knowledge/skill transfer

brain gain 508

clinical tourists 506

knowledge dupes 499

medical tourism, in 498

skilled health workers 506, 511

global inequalities in distribution 507-8

labour migration 39

see also forced labour; human trafficking; migrant workers; occupational health and safety

case study: Canada $242-8$

access to healthcare 246

gender bias 244

health challenges $245-6$

health selection 244-5

Migrant Agricultural Workers

Program 246-7

racialisation of labour 244

return migration from $247-8$

scale of 243
Seasonal Agricultural Workers

Program 243-7

Temporary Foreign Worker

Program 243

vulnerabilities 230, 237

feminisation of $127-8$

forced labour 234

global flows 234-5

destinations 235-6

origins $235-6$

Hukou system 39

industry sectors $236-7$

internal 19

labour programmes 230, 243-4

occupational health and safety risks 230-31, 240

phases of, health considerations of 237,238

destination 240-41, 245

interception 241, 247

pre-departure 238-9, 244-5

return $242,247-8$

travel 239-40, 245

pre-migration health 230

rural-to-urban 19,478

work permits 230

leave to remain

indefinite 312

left-behind households

see also health effects; remittances

gender inequality, and 36

labour migration, and 36

post-migration health effects $20-21$, 31-8

psychosocial processes $34-8$

remittances 33-4, 36

lifestyle migration see retirement migration

liminality 84, 181, 202, 205

malnutrition $34,217,387-8$

marriage migration 478

Medical Foundation for the Care of Victims of Torture 336

medical tourism 14, 129, 306, 434, 510-11

see also transnational care

brain drain, halting 509

definition 498, 501

destination country policies $498-9$ 
diasporic investment in 508-9

knowledge/skill transfer in 498

explicit knowledge 500

knowledge dupes 499

tacit knowledge 500

outcomes 505

perceptions of 502,510

promoting 498, 509

recruitment for 510

retirement migration, and 504

return migration policies, and 509

UK, from 503

Mediterranean migrant crisis see EU/ EAA

mental health 11

anxiety $29,35,83,177,181,182,423$

biomedical model of trauma 319 , 328

Chilean exiles in UK, of 324-5, 326-30

forced migration and 318

intervention pyramid 393

medicalisation of distress 319

post-traumatic stress disorder 186 , 220, 318, 319-20

psycho-social support, and 382

racism, and 82

resilience 320-22

community and 330-31

dynamic process, as 321

gender dimensions of 321,331 , 334-6

political activism, and 331, 332-3

solidarity, and 331-2

skill mismatch and 265-6

stressors 321 see also stress

trafficked persons, of see human trafficking

trauma 325

migrant background $13,44-5$

risk factor for infant weight gain 51

social determinant of health, as 55

migrants

annual increase in 19

definition 438

Eastern European in UK 422-4

health risks among see health risks

heterogeneous group 45

irregular see irregular migrants

survival see survival migration threat, as perceived 3-4, 113, 166

types of 478

migrant workers

see also labour migration

contract 233

definitions 231-2, 253

forced labourers 234

health vulnerabilities 237

health workers see health workers

highly skilled 233

housing 240

human rights of 231, 232

irregular 233-4

numbers of 232, 234

occupational health see occupational health and safety

rights 10, 79, 231, 232, 257

protecting $237,248,259-60$, 268-9, 270

seasonal 233, 236

temporary $233,236,478$

migration control

see also border control

borders in 137

child access to healthcare and see children; child welfare

medical evaluation as 143,145 , $147-8,150,306$

migration-health link 20, 38-9

see also left-behind households

healthy migrant hypothesis see health selection

left-behind households 21

mechanisms of 19-21, 39

post-migration health 23

pre-migration health 19, 23

survival see survival migration

migration policy 129

deservingness in see deservingness

disabled persons, and 299-300, 304-6

EU 461

precariousness in 207

receiving countries 96,158

children, towards 134-5, 196

restrictive 107, 135-6

source countries 127

vulnerability in $207-8$

migration status

see also precariousness 
determining 181-2

legal indeterminacy 143, 147

trauma, compounding 186

occupational health and safety, and see occupational health and safety

post-migration health and 28

precariousness of 79, 86, 208, 307

trafficked people, of see human trafficking 223

vulnerability and 269

young people, of 197

minority workers see migrant workers mobility $75,173-4,340,478$

HIV transmission and 340-41, 343, 347, 348-9

population flows 478

models 6-7, 44

acculturation 66-7

health transmission 46

healthy migrant effect $45-6,62-3$

life-course 46-9

morbidity $61-3$

see also health behaviour

child rates 37

chronic disease 46, 60

communicable disease 383

determinants of 65

implications 34

non-communicable disease $61-2,63$

psychiatric 242

reproductive 33

neonatal 384,439

risk factors for 59

mortality 61-3

cause specific 61

chronic disease 46, 60

climate-change-related 288

communicable disease 46,383

determinants of 65

implications 34

infant 385

maternal 384, 439

neonatal 33, 34, 64-5, 384, 439

non-communicable disease 61-2, 63

premature 357

risks 29,49

neoliberal globalisation see globalisation
New Economics of Labour Migration

(NELM) 33

non-communicable diseases $60,61,65$, 423

cardio-vascular disease 61-2, 63

global burden of 60

morbidity $61-2,63$

mortality $61-2,63$

obesity 24,63

child 50-52, 69

prevalence 63

risk factors for 65,70

Type 2 diabetes 85

urban refugees and 180

nutrition $33,387-8$

malnutrition $34,217,387-8$

occupational diaspora see labour migration; migrant workers

occupational health and safety 253

3-D jobs 254

determinants of 254,268

individual 260-61

macro-level 254-6

migration status 256-7

precarious work 256

work organisation 258-9

job ghettos 254, 264

labour migrants, of 240

layers of vulnerability framework 268-70

migration status and 261

personal protective equipment 260-61

risks $230-31$

skill mismatch 265-6

undocumented workers, of 257-8

workplace hazards

carcinogens 261-2

case study: Australia 262-4

workplace injustice $264-5$

work-related injuries 266-8

outreach work 164-6, 167, 246-7, 465

petty sovereignty 136, 138, 143

see also healthcare

discretionary judgements 138-9, 145-50

case studies $139-42,146$ 
post-migration health

children, of 36-7

as function of pre-migration health 28

left-behind households, of 20-21, 31-8

precariousness 9-10, 199, 207-8

see also vulnerability

employment, in 81, 83, 256, 269, 427-8

informal employment, of 81

irregular migrants, of 257

migration status, of 79, 86, 208, 307

newly-arrived migrants, of 160-67

precarity $198-9,207$

childhood, of 199-201

enforced return and 205-6

ongoing 201-2

re-emergence of 203-4, 207

pregnancy 51

see also birth outcomes

diet 68,69

mandatory testing 241

PTSD see mental health

racialisation $81-2$

definition 87

European care policies, of 306

women, of 78, 85, 86

work, of 244

racism

gendered 84

healthcare, in $82,99,161$

mental health effects 82

structural 84

refugee camps 12, 379

communicable diseases in 383-4 risk factors for 383

demographics of 380

employment, and 380-81

food security 387

healthcare provision in $187,382,385$ child 385-6

health risks in 382

HIV/AIDs in 386-7 see also HIV

host communities, and 381

humanitarian services in 381

maternal health in 384-5

mental health in 390-96

effective interventions 395-6

MHPSS 390-93 nutrition in $387-8$

reproductive health in $384-5$

sexual and gender-based violence in 388-9

refugees

see also repatriation; resettlement

-asylum seekers differentiation 460

definition 174, 438

exiles see exiles

internally displaced persons 381

local integration of 379

numbers of 379

protecting 388-90

children 390

resettlement to third country $379-80$

security 322

voluntary repatriation of 379

remittances 31

gendered responsibilities and 76, 83

health effects of $32,33-4,54$

socioconomic benefits of $35,36,38$, 126,242

repatriation

burial, for 517, 520, 522-3, 525-6

end-of-life 517-18

pregnant women, of 241

terminally-ill migrants, of 242, 247

voluntary 379

reproductive health

see also sexual health

definition 439

female genital mutilation 440

forced marriage 440

right to 439

risks 384

young people, of 439-41

challenges $445-6$

resettlement 184-6, 286-7,

third country, to $379-80$

residential tourism see retirement migration

retirement migration 478

destinations 403

European Health Insurance Card 408

return for care 413-14, 416

Spain, to 404-5

access to healthcare 407-9, 411-12

cultural barriers $410-11$

language barriers 411 


\section{Handbook of migration and health}

social care $409-10$

third age, during 405-6, 415

voluntary sector $412-13$

return migration 83

deportation see deportation

forced see deportation

healthcare, for 413-14

health consequences of 242

health selection see health selection

health status on 231

modes of 242

'salmon' bias hypothesis $21,24-5$, 516

risk factors

child obesity, for 51

migrant background as 51, 55

segmented assimilation 68

segregation 50

sexual and gender-based violence 384 , 388-90

children, against 390

intimate partner violence 389

protection against 389

refugee camps, in 389

women at risk of 184,186

sexual health 439

see also reproductive health

education 447-9

forced marriage 440

promotion, culture and 441-2

right to 439

sex work 440

young people, of 439-41

SGBV see sexual and gender-based violence

situated transnationalism 492

see also transnational families

social benefits 21

social capital 52, 126, 424, 498-9

social cohesion 54

social determinants of health and wellbeing 3, 52-4, 99, 424

social mobility 82

social relationships $82-3$

social stratification $81-2$

socioeconomic factors

benefits $21,35,36,38,126,242$

costs 21

inequalities 53, 64 left-behind households $31-8,47$

status $52,53,66,77,185,230,237$, 239-40, 427

socio-spatial dimensions of healthcare new migrants in France, of 158-9, 160-61

accommodation 164

immigration status 160

language issues 160

media representation 160-61

mobility $161-3$

universalism 165-6

South Africa

destination country, as 125, 177, 348

end-of-life-care in 517

destitute migrants, for 519-20

returning home to die 517-8

high prevalence of HIV/AIDS 516

source country, as 125

xenophobia in 179

Spain

retirement migration to $404-5$

access to healthcare 407-9, 411-12

cultural barriers $410-11$

fourth age, during 406-7, 415

language barriers 411

social care 409-10

third age, during 405-6, 415

voluntary sector $412-13$

stress $84-5$

see also mental health

health inequity, as $84-5$

mitigating 87

stressors $79,82,321$

anxiety $29,35,83,177,181,182$, 423

guilt $83,220,311,485$

survival migration $173-4$

see also forced migration

children, of see children

definition 174-6

detention of migrants 181-3

children 183-4

gender-based violence in 186-7

internal displacement 175, 176-7

scale of 176

transit countries 179-80

trafficked persons see human

trafficking 
trafficking see human trafficking transit countries 179-80

transnational care 505

see also health workers; medical tourism

health workers 506-10

transnational families 477, 486

care circulation/exchanges 479-80, 484-5, 486-7

implications of 493-4

new media, and 487-9

policy challenges $491-3$

portability of care 489-90

definition 479

extended kinship 485-6

mothering 485-7

transnational networks 13-15

extended kinship 485-6

solidarity $323,330-31,335$

tuberculosis see communicable diseases, TB

UDHR see Universal Declaration of Human Rights

unaccompanied minors 195

see also children; deservingness; vulnerability

age assessment 196

health outcomes $187-8$ mental 196

legal status of 195, 197

numbers of 195-6

precariousness of 199, 207-8

precarity of 199-201

trafficking of 196

transition to adulthood 195-7, 199, 203, 206

vulnerability of 196, 197-9

wellbeing of 197-8

unauthorised migrants see irregular migrants

UNCRC see United Nations

Convention on the Rights of the Child

undocumented migrants see irregular migrants

unfree labourers see migrant workers

United Kingdom

see also medical tourism; Spain

Chilean exiles in $322-4$ access to healthcare $326-30$

mental health 324-5

chronic illness among asylum seekers, in 308-12

disability among asylum seekers, in 308-12

eastern European migrants in 422-4

employment law 257

medical tourism from 503

return migration to 413-14

United Nations Convention on the

Rights of Persons with Disabilities

(2008) 300, 302-3, 304

see also disabled persons; disability

Article 18303

United Nations Convention on the

Rights of the Child 134, 419

see also children; young people

United Nations High Commissioner

for Refugees 176, 303-4, 379, 383, 388,390

Health Information system 388

mandate 381

non-discriminatory policy 380

resettlement programmes 184,380

United Nations International

Convention on the Protection

of the Rights of All Migrant

Workers and Members of their

Families (1990) 224

United Nations Millennium

Declaration (2000) 439

United Nations Optional Protocol on the Prevention, Suppression and

Punishment of Trafficked Persons, Especially Women and Children (2000) 223

see also human trafficking

United States of America

deportation from 174

employment law 255

female migrants in 36

health worker shortfall 120

Mexican migration to 23, 33, 239

left-behind households 35

Occupational Safety and Health

Administration (OSHA)

255-6

xenophobia in 107 


\section{Handbook of migration and health}

Universal Declaration of Human

Rights 122 see also human rights

universalism 38

visible minority workers see migrant workers

voluntary migration 44

see also labour migrants; retirement migration

vulnerability 4, 9-10

see also children; irregular migrants; unaccompanied minors; women children, of 187-8, 206

deportation, to see deportation deported minors, of 205

elderly people, of 407

migrants in transit, of $177-8$

-precariousness differentiation 197-8

structural 248

trafficked persons, of 241

undocumented migrants, of 233-4, 241

women, of 241

welfare dependency 491

women

discrimination against 255

'hero's wife', as 335

vulnerability of 241

World Conference on Women (4th, 2015) 439

Beijing Declaration 439

World Health Organization

Cultural Contexts of Heath programme 464 definition of health 382

Global Code of Practice on the International Recruitment of Health Personnel 125, 128

High Level Meeting on Refugee and Migrant Health (2015) 459

Manual for the Health Care of Children in Humanitarian Emergencies (2008) 385-6

young people

see also children

accessing healthcare 427-9, 446

Australia, in 444-5

adaptation to new situation 423-4

barriers to health 429

cultural factors 431-2, 445

lack of information 429-31

language 432-3

carers, as $310-12$

support for 312

conducting research with 425-6

health behaviours 426-7, 435

healthcare for 419-20

challenges of 434, 445-6

mental health issues 424

mobility of 478

sexual health 438

culturally competent services 450-42

-reproductive health overlap 439

youth-friendly services $449-50$

reproductive health 438

'voice' in healthcare 13, 419, 421-2 